\title{
Jakość złączy z wysokowytrzymałych stali spawanych elektrodą nietopliwą w osłonie mieszanki $\mathrm{Ar}+\mathrm{H}_{2}$
}

\author{
Quality of high strength steel joints welded with $\mathrm{Ar}+\mathrm{H}_{2}$ shield- \\ ing gas
}

\section{Streszczenie}

Przeprowadzono badania spawania elektrodą nietopliwą wysokowytrzymałych, drobnoziarnistych stali ferrytycznych z niewielkim dodatkiem wodoru do mieszanki osłonowej na bazie argonu. Wykazano, że dodatek wodoru na poziomie do $2 \%$ nie wpływa na powstawanie zwłocznych pęknięć wodorowych przy zachowaniu rygorystycznych reżimów technologicznych na etapie przygotowania i oczyszczenia stali przed i po spawaniu. Kontrolowany dodatek wodoru pochodzący z mieszanki osłonowej ma pozytywny wpływ na jakość złączy. Dzięki obecności $2 \%$ wodoru złącza charakteryzują się głębszym wtopieniem, mniejszą skłonnością do podtopień krawędzi oraz gładkim licem. Spełniają wymagania systemu zapewnienia jakości w spawaniu. W artykule przedstawiono wyniki badań skłonności do pęknięć zimnych w próbie Tekken złączy spawanych elektrodą nietopliwą w ostonie mieszanek argonu z wodorem wybranych gatunków stali o strukturze bainityczno-ferrytycznej.

Słowa kluczowe: gazy osłonowe; stale ferrytyczne; argon; wodór

\begin{abstract}
Testing of joints made during welding with a GTAW of high-strength, fine-grained ferritic steels confirms that a small addition of hydrogen to the argon-based shielding mixture does not affect the formation of hydrogen cracking. Is very important to pay attention to strictly adhere to the technological regimes during steel preparation before and after welding. Then the controlled addition of hydrogen coming from the casing mixture has a positive effect. Due to the presence of $2 \%$ hydrogen, the joints are characterized by deeper penetration, lower inclination to edge flooding and smooth face. They are technically correct and impeccable in terms of aesthetics.
\end{abstract}

Keywords: gas shield in welding; ferritic steels; argon; hydrogen

\section{Wstęp}

Dążenie do produkowania niezawodnych wyrobów o dobrej jakości skłania wytwórców do postrzegania wszystkich procesów produkcyjnych z różnych perspektyw, a ostateczną ocenę jakości wytwarzanych wyrobów należy traktować jako wypadkową ich właściwości technicznych, estetycznych oraz warunków ekonomicznych i środowiskowych, w jakich zostały wykonane. Dotyczy to również wyrobów spawanych, co do jakości, których pogląd na przestrzeni ostatnich kilkudziesięciu lat zmienił się diametralnie $[1 \div 5]$. Jeszcze 20 czy 30 lat temu wystarczyło, że wyrób spawany spełniał wymagania wytrzymałościowe, a jeśli jednocześnie był wykonany estetycznie, to było to swego rodzaju wartością dodatkową. Obecnie stało się to normą. Oczywiście nie jest tak, że wszystkie wyroby muszą spełniać takie same warunki. Zależy to od funkcji, jakie spełniają. I tak inne wymagania co do jakości technicznej i estetycznej muszą spełniać części motoryzacyjne czy AGD, a inne elementy konstrukcji mostów. Niewątpliwie spełnianie tych wszystkich wymagań sprawia wiele kłopotów. I czasami pomimo prawidłowego przygotowania złącza, odpowiednio dobranego materiału i wyszkolonego personelu, występują problemy z wykonaniem połączeń o odpowiednio wysokiej jakości. Część produktów nie ma dostatecznie dobrego wyglądu i chociaż technicznie jest poprawna to zostaje złomowana.

Przyczyn takiego stanu rzeczy może być wiele, szczególnie wówczas gdy wystąpią one razem. Znaczący wpływ ma skład chemiczny stali, naprężenia wewnętrzne po wcześniejszych obróbkach oraz niewłaściwa ilość ciepła wprowadzona do złącza. Jednym ze sposobów zapobiegania temu może być zastosowanie odpowiednio skomponowanej

Dr hab. inż. Tadeusz Sałaciński, prof. PW - Politechnika Warszawska; mgr inż. Wojciech Sosnowski - PWSZ Ciechanów.

Autor korespondencyjny/Corresponding author: wojciech.sosnowski@pwszciechanow.edu.pl 
gazowej mieszanki osłonowej. Sposób ten może być sku-

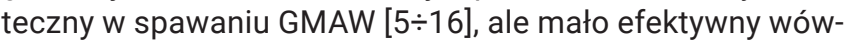
czas gdy konieczne jest wykonanie złącza elektrodą nietopliwą (GTAW). Chociaż metoda uważana jest za precyzyjną i „szlachetną”, to ma znaczne ograniczenia dotyczące osłony gazowej ze względu na wysokotemperaturowe powinowactwo chemiczne wolframu do tlenu. Jako gaz ochronny do spawania metodą TIG można zastosować czysty argon do spawania stali ferrytycznych oraz mieszankę $\mathrm{Ar} z$ niewielkim dodatkiem $\mathrm{H}_{2}$ do spawania, jak się powszechnie przyjmuje, stali austenitycznych (metoda $145 \mathrm{wg}$ PN-EN

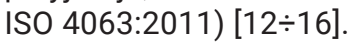

\section{Oddziaływanie wodoru na stal}

Wiadomym jest, że wodór, który znajdzie się w strukturze stali może zmieniać jej właściwości zarówno mechaniczne, jak i chemiczne, szczególnie gdy jest zaabsorbowany w dużej ilości. Wielkość tych zmian uzależniona jest głównie od składu chemicznego, mikrostruktury, zanieczyszczeń, a także rodzaju obróbek, jakim stal została poddana.

Degradacja właściwości mechanicznych charakteryzująca się obniżeniem parametrów wytrzymałościowych i plastycznych ma ogromne znaczenie przy spawaniu stali ferrytycznych, w których wodór rozpuszcza się słabo, przyczyniając się do pękania zwłocznego. Może on być również przyczyną pęknięć wskutek korozji naprężeniowej, wywołanej utworzeniem się galwanicznych ogniw wodorowych. Współczesne badania wykazują, że elektrochemiczne nawodorowanie znacznie zmniejsza odporność korozyjną metali i stopów z racji zdefektowania powierzchni oraz powstałych wżerów korozyjnych. Pęknięcia powstają w wyniku różnej ilości pochłoniętego wodoru w wierzchołkach oraz ściankach szczelin, co wpływa na wydłużenie szczeliny, a w efekcie zmniejsze-

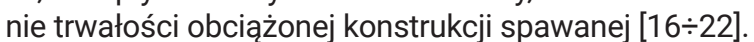

Wodór w warunkach normalnych występuje w postaci cząsteczkowej $\mathrm{H}_{2}$, jest to dla niego postać neutralna energetycznie. W takiej formie jest on mało aktywny chemicznie. Inaczej rzecz się ma, kiedy wodór dysocjuje do postaci atomowej. Wówczas reaguje on prawie ze wszystkimi pierwiastkami. Tworzy wiązania jonowe, kowalencyjne i metaliczne. Atomy wodoru są na tyle małe, że mogą swobodnie przemieszczać się w strukturze krystalicznej metalu, a łącząc się, tworzą wodór cząsteczkowy, który jeśli znajdzie się wewnątrz struktury metalu może być niebezpieczny. Dla konstrukcji spawanych proces jest tym bardziej szkodliwy, ponieważ pęknięcie w obrębie spoiny może nastąpić po ostygnięciu złącza, np. po upływie 24 czy 48 godzin od wykonania. Niebezpieczny charakter pęknięć zimnych wynika stąd, że mogą ujawnić się, wówczas gdy nad konstrukcją nie ma już nadzoru, złącza są pomalowane lub nawet często wbudowane w ustrojach nośnych.

Reasumując nieciągłości w materiałach, szkodliwe oddziaływanie wodoru oraz naprężenia rozciągające mogą być przyczyną rozpatrywanych zwłocznych pęknięć zimnych, zwanych również wodorowymi.

\section{Wpływ wodoru zawartego w mieszance osłonowej na przebieg procesu spawania elektrodą nietopliwą}

Proces dysocjacji wodoru jest endotermiczny i żeby wystąpił, niezbędne jest dostarczenie odpowiedniej ilości energii (np. cieplnej). Rozpad cząsteczki wodoru może nastąpić również w otoczeniu wyładowania elektrycznego. Biorąc pod uwagę omawiany proces spawania, to są tu spełnione obydwa te warunki jednocześnie.

Ściśle kontrolowana ilość wodoru w mieszaninie z argonem przepływa wokół elektrody wolframowej. W warunkach spawania zachodzi proces dysocjacji termicznej cząsteczki wodoru wskutek pochłaniania określonej ilości energii cieplnej. W wyniku tego temperatura łuku wokół elektrody znacznie się obniża. Jest to zjawisko korzystne, ponieważ zużycie elektrod jest mniejsze. Następnie atomy przy zetknięciu się z powierzchnią materiału spawanego oddają pochłonięte ciepło, z powodu czego metal topi się szybciej. Jeziorko ciekłego metalu wykazuje niższe napięcie powierzchniowe, a to z kolei powoduje mniejszą skłonność do podtopień krawędzi. Atomy oddając ciepło łączą się ponownie w cząsteczki $\mathrm{H}_{2}$. Temperatura łuku wzrasta również wskutek spalania się wodoru w tlenie, który przedostaje się z powietrza. Zawężenie łuku daje węższą spoinę, a łuk o wyższej energii pozwala na zwiększenie wtopienia i prędkości spawania. Poza tym wodór zawarty $\mathrm{w}$ mieszance redukuje tlenki $[5,8,9,16]$.

\section{Badania własne}

Powszechne przekonanie o szkodliwym wpływie wodoru na stal oraz to, że jest on jedną z przyczyn bardzo niebezpiecznych pęknięć wodorowych w obszarze złączy spawanych, powoduje obawę przed jego stosowaniem w osłonowych mieszankach gazowych na bazie argonu. Dotyczy to szczególnie spawania stali ferrytycznych, dla których współczynnik dyfuzji wodoru w sieci krystalicznej jest wysoki a rozpuszczalność niska. Szkodliwy wpływ wodoru na metale jest bezsporny, szczególnie gdy zostanie on zaabsorbowany w dużej ilości. Jednak jego niewielki, kontrolowany dodatek do osłony gazowej na bazie argonu na proces spawania stali ferrytycznych GTAW nie jest szeroko opisany w literaturze. W tym celu przeprowadzono badanie złączy spawanych z wysokowytrzymałych, drobnoziarnistych stali o minimalnej granicy plastyczności $500 \mathrm{MPa}$ i $700 \mathrm{MPa}$.

Zastosowane podczas eksperymentu nowoczesne gatunki stali wysokowytrzymałych, walcowanych na gorąco, odznaczają się wysoką jakością oraz znakomitymi własnościami inżynieryjnymi. Są podatne na gięcie, zachowując przy tym doskonałą jakość powierzchni. Złącza spawane wykonane z tych stali mają wysoką wytrzymałość i udarność w strefie wpływu ciepła, co zapewnia im dobrą odporność na pękanie kruche $[11,13,17,23 \div 25]$. Przy zachowaniu rygorów technologicznych omawiane gatunki stali są dobrze spawalne, lecz ze względu na skład chemiczny i strukturę krystaliczną ich wspólną cechą jest podatność na zwłoczne pęknięcia wodorowe. W artykule przedstawiono wyniki badań skłonności do pęknięć zimnych w próbie Tekken złączy spawanych elektrodą nietopliwą w osłonie mieszanek argonu z wodorem wybranych gatunków stali o strukturze bainityczno-ferrytycznej. Przeprowadzono test "Y" spoin czołowych na blachach grubości $10 \mathrm{~mm}$ wg PN-EN ISO 17642-2:2005. Próba ta polega na wykonaniu złącza dwóch płyt o wymiarach 200 x 75 mm, ukosowanych w specjalny sposób (rys. 1).

Złącza poddane były badaniom NDT w czasie 72 godz. od wykonania, tak aby z całą pewnością wykluczyć pęknięcia zimne. Następnie spoiny próbne zostały pocięte na odcinki o szerokości ok. $10 \mathrm{~mm}$ i poddane badaniom metalograficznym. W poszukiwaniu mikropęknięć próbki szlifowano co ok. $1 \mathrm{~mm}$.

Do badania użyto 3 gatunki drobnoziarnistych stali o wysokiej wytrzymałości: DOMEX ${ }^{\circledR}$ S500ML, STRENX ${ }^{\circledR}$ S700MC oraz STRENX ${ }^{\circledR}$ S700MC E. Płyty próbne wykonano w osłonie 


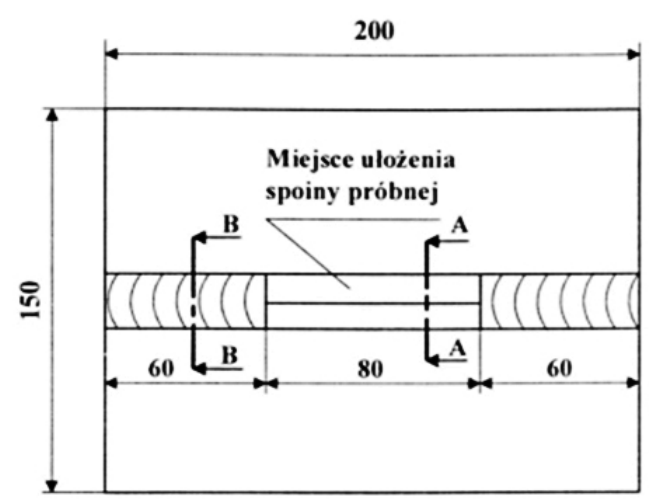

$\underline{A-A}$

$\underline{\text { B - B }}$
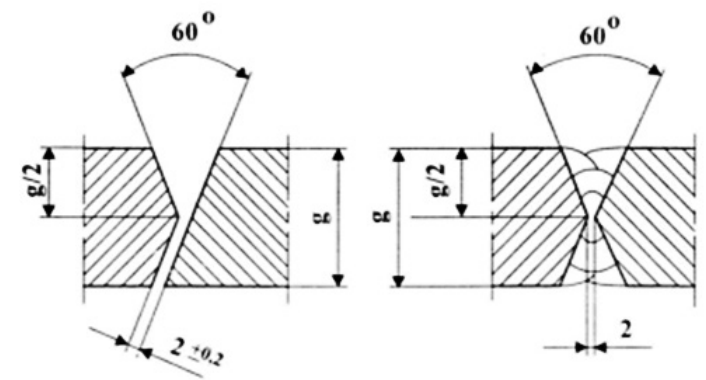

Rys. 1. Przygotowanie płyty do próby Tekken (źródło: PN-EN ISO 17642-2:2005)

Fig. 1. Conditions of geometrical preparing of Tekken testing plate

3 mieszanek argonu z wodorem z grupy R1 (wg PN-EN ISO 14175):

1) $98 \% \mathrm{Ar}+2 \% \mathrm{H}_{2}$ zalecanej do spawania ręcznego,

2) $95 \% \mathrm{Ar}+5 \% \mathrm{H}_{2}$,

3) $90 \% \mathrm{Ar}+10 \% \mathrm{H}_{2}$ dedykowanych do spawania zmechanizowanego.

Złącza porównawcze z ww. gatunków stali spawano w osłonie zawierającej 100\% Ar (I1, wg PN-EN ISO 14175).

Stanowisko badawcze do eksperymentu przygotowano w sposób pozwalający na skuteczne unieruchomienie płyt stalowych, tak aby elektroda przemieszczała się w osi próbki. Wszystkie spoiny były wykonane przy pomocy wózka spawalniczego pozwalającego na utrzymanie zarówno stałej prędkości spawania jak i długości łuku. Zastosowanie wózka spawalniczego umożliwiło również rozszerzenie badań przez zastosowanie mieszanek zalecanych do spawania zmechanizowanego (2 i 3) w celu zweryfikowania czy pęknięcia wystąpią w połączeniach wykonanych z podwyższoną zawartością wodoru.

Przed spawaniem płyty próbne były podgrzane osuszająco do temperatury $70 \div 80{ }^{\circ} \mathrm{C}$. Po spawaniu próbki nie były wygrzewane, tylko odkładane na blat stalowy podgrzany do temperatury ok. $50 \div 60{ }^{\circ} \mathrm{C}$. Temperatura pomieszczenia, w którym wykonywano próbki wynosiła $26^{\circ} \mathrm{C}$, a wilgotność względna $52 \%$.

Prezentowane gatunki stali cechuje wysoka plastyczność i jednocześnie niska temperatura przejścia w stan kruchy (tabl. I). Dlatego też ich stosowanie uzasadnione jest wszędzie tam, gdzie konieczna jest redukcja masy konstrukcji przy zachowaniu niezbędnej nośności, a pośrednio również i obniżenie kosztów wytwarzania. Należy zwrócić uwagę,

Tablica I. Wybrane wskaźniki spawalności badanych gatunków stali Table I. Selected weldability coefficient of tested steel types

\begin{tabular}{|c|c|c|c|c|c|c|}
\hline Stal & Zawartość C [\%] & Równoważnik C $C_{\mathrm{EV}}$ & Równoważnik $\mathrm{C}_{\mathrm{ET}}$ & Równoważnik $\mathrm{H}_{\mathrm{Cs}}$ & Temp. podgrzew. [ $\left.{ }^{\circ} \mathrm{C}\right]$ & Udarność KV \\
\hline S500ML & 0,136 & 0,43 & 0,30 & 1,04 & 157 & $40 \mathrm{~J} /-60^{\circ} \mathrm{C}$ \\
\hline S700MC & 0,060 & 0,39 & 0,29 & 0,13 & 140 & $27 \mathrm{~J} /-50^{\circ} \mathrm{C}$ \\
\hline S700MC E & 0,152 & 0,41 & 0,25 & 1,36 & 149 & $69 \mathrm{~J} /-40^{\circ} \mathrm{C}$ \\
\hline
\end{tabular}

że omawiane gatunki stali mają stosunkowo wysoką wartość równoważnika węgla $\mathrm{C}_{\mathrm{EV}}$ przy bardzo niskiej zawartości węgla. Za ten fakt odpowiadają mikrododatki stopowe oraz wysoka zawartość manganu (ok. 2,0\%).

Przy spawaniu drobnoziarnistych stali o wysokiej wytrzymałości istotna jest kontrola techniki spawania oraz ilości wprowadzonego ciepła. Dla omawianych gatunków stali proces spawania należy prowadzić tak, aby energia liniowa nie przekroczyła wartości $1 \mathrm{~kJ}$ na każdy mm długości spoiny. Ma to związek z tzw. temperaturą przejścia w stan kruchy $\left(T_{\text {psk }}\right)$, która zależna jest m.in.: od składu chemicznego stali, obróbki cieplnej, a także procesu wytwarzania. Odpowiednia technologia produkcji ma zasadnicze znaczenie, ponieważ najważniejszym czynnikiem, który wpływa na obniżenie $\mathrm{T}_{\text {psk }}$ i jednocześnie na zwiększenie granicy plastyczności jest wielkość ziarna. Stąd też parametry spawania należy dobierać tak, aby nie prowadziły do jego nadmiernego rozrostu. Natężenie prądu spawania i napięcie łuku oraz prędkość spawania w eksperymencie ustalono na takim samym poziomie dla wszystkich prób (tabl. II), ale tak, aby energia liniowa była znacznie poniżej wartości dozwolonej. Dobierano je na podstawie badań wstępnych wykonywanych w czasie spawania w osłonie czystego argonu w taki sposób, aby spełniały dwa warunki. Po pierwsze przyjęto założenie, że nawet ok. $10 \%$ „wzmocnienie” łuku spawalniczego dodatkiem wodoru do osłony ciekłego jeziorka nie spowoduje przekroczenia wartości energii liniowej dopuszczalnej przez producenta stali i warunek drugi, polegający na ocenie kształtu przekroju poprzecznego spoiny oraz wyglądu lica do uzyskania minimum poziomu jakości C wg PN-EN ISO 5817. Wartość energii liniowej spełniająca założenia do badań kształtuje się na poziomie $0,8 \mathrm{~kJ} / \mathrm{mm}$.

Tablica II. Parametry spawania płyt próbnych Table II. Welding parameters of tested joints

\begin{tabular}{|c|c|c|c|c|}
\hline $\begin{array}{c}\text { Natężenie } \\
\text { [A] }\end{array}$ & $\begin{array}{c}\text { Napięcie } \\
\text { łuku } \\
\text { [V] }\end{array}$ & $\begin{array}{c}\text { Prędkość } \\
\text { spawania } \\
\text { [mm/min] }\end{array}$ & $\begin{array}{c}\text { Energia } \\
\text { liniowa } \\
{[\mathrm{J} / \mathbf{m m}]}\end{array}$ & $\begin{array}{c}\text { Wydatek } \\
\text { osłony gazo- } \\
\text { wej [l/min] }\end{array}$ \\
\hline 190 & 13,5 & 120 & 770 & 8 \\
\hline
\end{tabular}

Fotografie na rysunku 2 przedstawiają przykładowe próbki Tekken wykonane w czterech różnych osłonach gazowych. $\mathrm{Na}$ rysunku 2a, wykonanej ze stali S700MC E walcowanej na gorąco, spawanej w osłonie czystego argonu widać wyraźne podtopienia krawędzi i nierówności lica. Strzałką zaznaczono zauważone podtopienia krawędzi, zwiększające się zgodnie z kierunkiem spawania, czyli wraz z narastającą temperaturą blach. Na rysunku $2 \mathrm{~b}$ pokazano próbkę ze stali S500ML, walcowanej termomechanicznie, spawanej w osłonie $\operatorname{Ar} z 2 \%$ dodatkiem $\mathrm{H}_{2}$. Widoczny brak podtopień oraz gładkie lico. Najbardziej gładkie lico i również brak podtopień krawędzi uzyskano w próbie ze stali S700MC (rys. 2c), również walcowanej termomechanicznie, chronionej mieszanką 95\% argonu i 5\% wodoru. Rysunek 2d przedstawia spoinę próbną ze stali S500ML spawaną w osłonie mieszanki Ar i $10 \%$ dodatku wodoru. W tym przypadku przy zadanych parametrach prądowych stwierdzono trudności w wykonaniu połączenia, głównie ze względu na zbyt wysoką wartość 

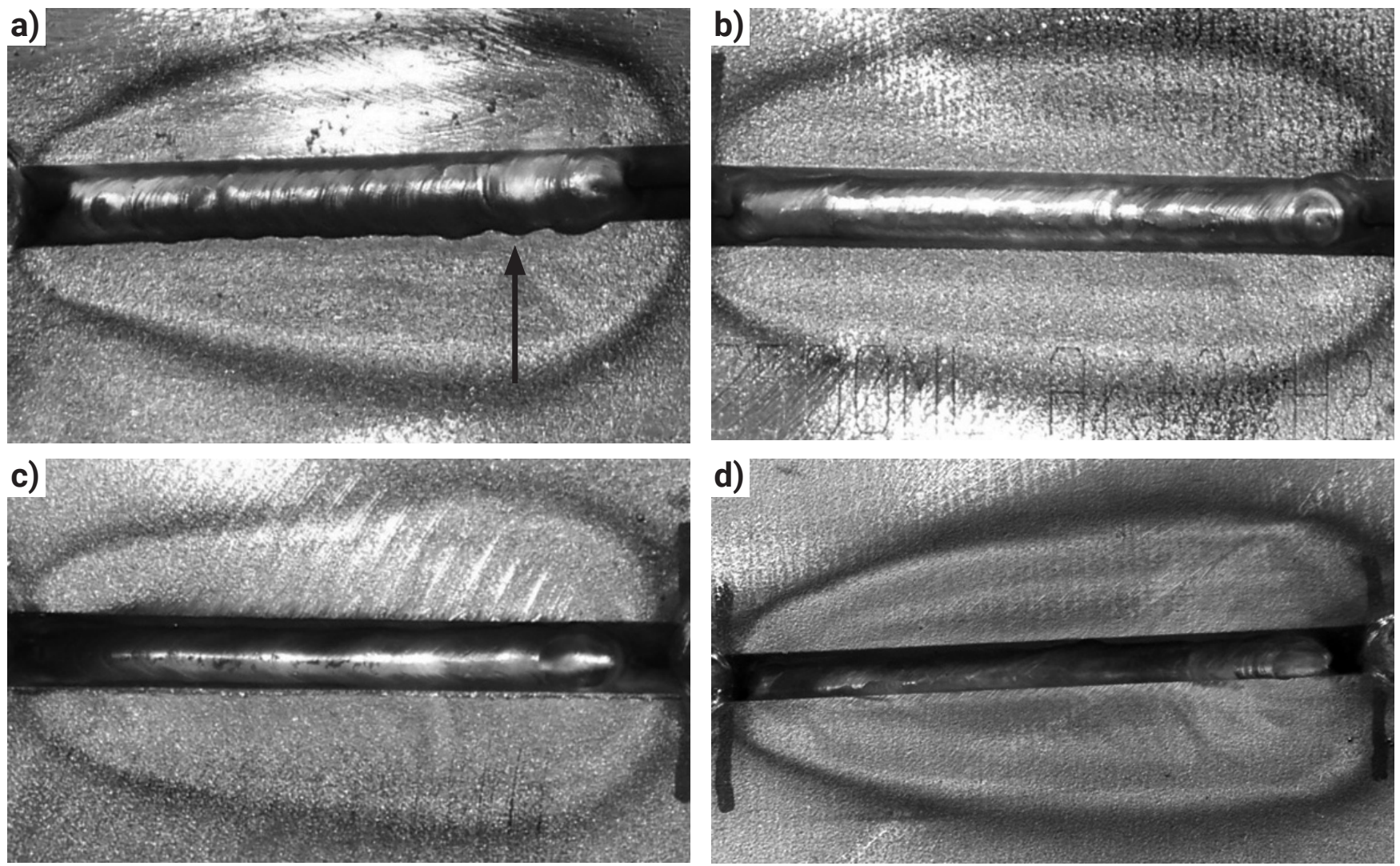

Rys. 2. Płyty do próby Tekken: a) S700E, osłona $100 \% \mathrm{Ar}$, b) S500ML, osłona $\mathrm{Ar}+2 \% \mathrm{H}_{2}$, c) S700MC, osłona $\mathrm{Ar}+5 \% \mathrm{H}_{2}$, d) $\mathrm{S} 500 \mathrm{ML}$, osłona $\mathrm{Ar}+10 \% \mathrm{H}_{2}$

Fig. 2. Steel plates for Tekken test: a) $\mathrm{S} 700 \mathrm{E}$, gas shield $100 \% \mathrm{Ar}$, b) $\mathrm{S} 500 \mathrm{ML}$, gas shield $\mathrm{Ar}+2 \% \mathrm{H}_{2}$, c) $\mathrm{S} 700 \mathrm{MC}$, gas shield $\mathrm{Ar}+5 \% \mathrm{H}$, d) S500ML, gas shield $\mathrm{Ar}+10 \% \mathrm{H}_{2}$

energii liniowej wynikającą ze znacznie wyższej mocy łuku spawalniczego pod wpływem wodoru zawartego w mieszance gazowej.

W czasie badań wizualnych zaobserwowano charakterystyczne ukształtowanie strefy wpływu ciepła (SWC) dla próbek wykonanych w poszczególnych mieszankach osłonowych.

I tak SWC złącza spawanego w osłonie czystego Ar ma kształt zbliżony do „gruszki”, gdy SWC połączeń w mieszankach $\mathrm{Ar} z \mathrm{H}_{2}$ jest równomierna od początku do końca, kształtem zbliżona do „cygara”. Oznacza to, że spawanie z dodatkiem wodoru pozwala na osiągnięcie optymalnych warunków natychmiast po rozpoczęciu procesu, natomiast przy spawaniu w samym Ar dochodzenie do właściwego poziomu energii trwa dłużej. Należy zwrócić uwagę na charakterystyczny wygląd spoiny na rysunku 2 d, uwidaczniający tlenki wysokotemperaturowe na powierzchni blachy (szczególnie w pierwszych 3 godzinach po zakończeniu spawania). Świadczy to o znacznie wyższej energii dostarczonej do złącza.

W czasie badań wizualnych nie stwierdzono wad spawalniczych w złączach próbnych ani też pęknięć w czasie 72 godzin po spawaniu (tabl. III).

W celu wykluczenia możliwości przeoczenia ewentualnych pęknięć badania wizualne prowadzono po 24 godz., 48 godz. i 72 godz. po zakończeniu spawania próbek. Do cięcia spoin próbnych zastosowano piłę taśmową.

Rysunki $3 \div 6$ przedstawiają fotografie makrostruktury zgładów stali S500ML wykonanych w omawianych osłonach gazowych. Stwierdzono znaczny wzrost głębokości wtopienia wraz ze zwiększaniem dodatku wodoru do osłony gazowej. Widoczny jest nieznaczny rozrost ziarn dla wszystkich prób, płynnie zwiększający się od linii wtopienia do osi spoiny. Kryształy ułożone są dłuższą osią w kierunku krystalizacji. Próbki ze stali S500ML charakteryzują się największymi różnicami zarówno we wtopieniu, jak i grubości spoiny.
Tablica III. Raport z badań wizualnych Table III. VT raport

\begin{tabular}{|c|c|c|c|}
\hline Lp. & Gatunek stali & Osłona gazowa & Po 72 godz. \\
\hline 1 & \multirow{4}{*}{ S $500 \mathrm{ML}$} & $\mathrm{Ar}$ & Brak pęknięć \\
\hline 2 & & $\mathrm{Ar}+2 \% \mathrm{H}_{2}$ & Brak pęknięć \\
\hline 3 & & $\mathrm{Ar}+5 \% \mathrm{H}_{2}$ & Brak pęknięć \\
\hline 4 & & $\mathrm{Ar}+10 \% \mathrm{H}_{2}$ & Brak pęknięć \\
\hline 5 & \multirow{4}{*}{ S $700 \mathrm{MC}$} & $\mathrm{Ar}$ & Brak pęknięć \\
\hline 6 & & $\mathrm{Ar}+2 \% \mathrm{H}_{2}$ & Brak pęknięć \\
\hline 7 & & $\mathrm{Ar}+5 \% \mathrm{H}_{2}$ & Brak pęknięć \\
\hline 8 & & $\mathrm{Ar}+10 \% \mathrm{H}_{2}$ & Brak pęknięć \\
\hline 9 & \multirow{4}{*}{ S 700MC E } & $\mathrm{Ar}$ & Brak pęknięć \\
\hline 10 & & $\mathrm{Ar}+2 \% \mathrm{H}_{2}$ & Brak pęknięć \\
\hline 11 & & $\mathrm{Ar}+5 \% \mathrm{H}_{2}$ & Brak pęknięć \\
\hline 12 & & $\mathrm{Ar}+10 \% \mathrm{H}_{2}$ & Brak pęknięć \\
\hline
\end{tabular}

W odniesieniu do złącza porównawczego (osłona 100\% Ar) różnica głębokości we wtopieniu spoiny liczona od powierzchni blachy do grani spoiny wyniosła o ok. $20 \div 21 \%$ więcej dla mieszanek z $2 \%$ i $5 \%$ dodatkiem wodoru i o $36 \%$ więcej, niż gdy zastosowano osłonę z dodatkiem $10 \%$ wodoru (rys. 7). Jeszcze większe różnice zarejestrowano mierząc grubość spoiny dla tego gatunku stali. Odnotowano odpowiednio $24 \%$, 31\% i $77 \%$ wzrost dla poszczególnych mieszanek osłonowych na bazie $\operatorname{Ar} z$ dodatkiem $\mathrm{H}_{2}$ w stosunku do złącza wykonanego w osłonie argonu (rys. 8). 

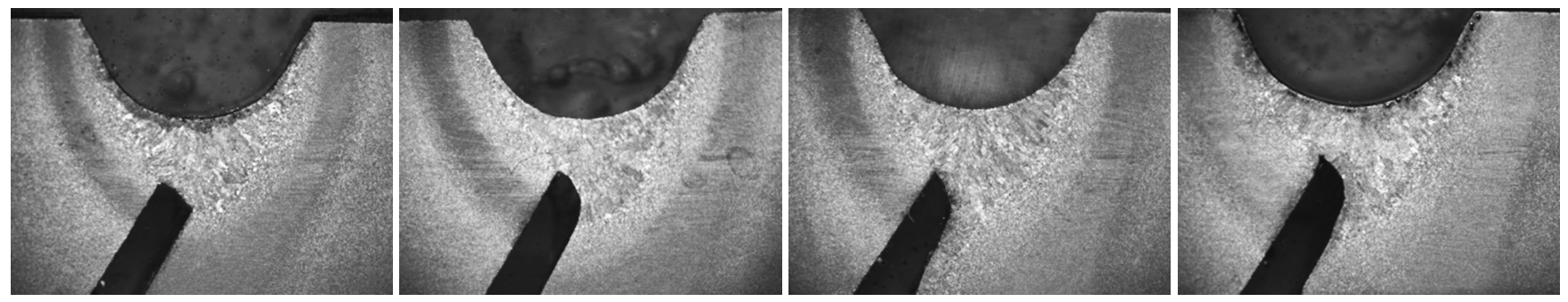

Rys. 3. Makrostruktura złącza spawanego S500ML, osłona $100 \% \mathrm{Ar}$

Fig. 3. Macrostructure of S500ML welded joints, shielding gas $100 \% \mathrm{Ar}$
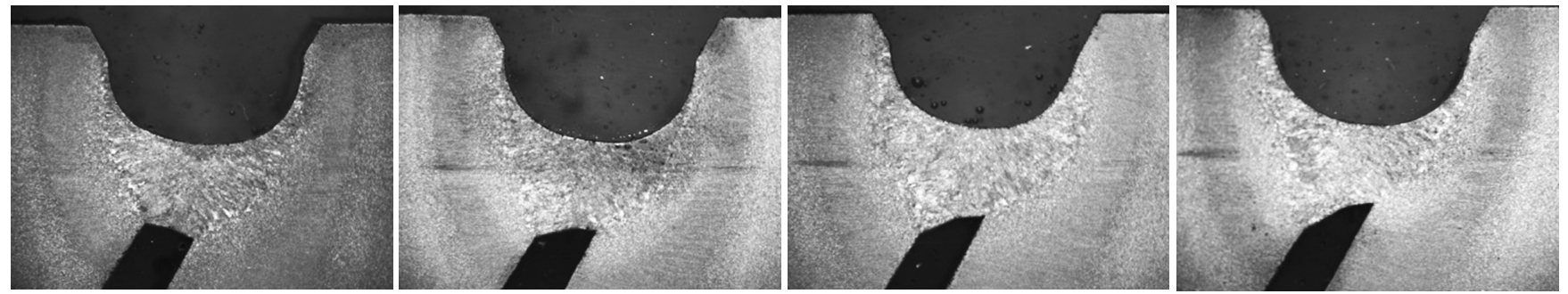

Rys. 4. Makrostruktura złącza spawanego $\mathrm{S} 500 \mathrm{ML}$, osłona $\mathrm{Ar}+2 \% \mathrm{H}_{2}$

Fig. 4. Macrostructure of S500ML welded joints, shielding gas $\mathrm{Ar}+2 \% \mathrm{H}_{2}$
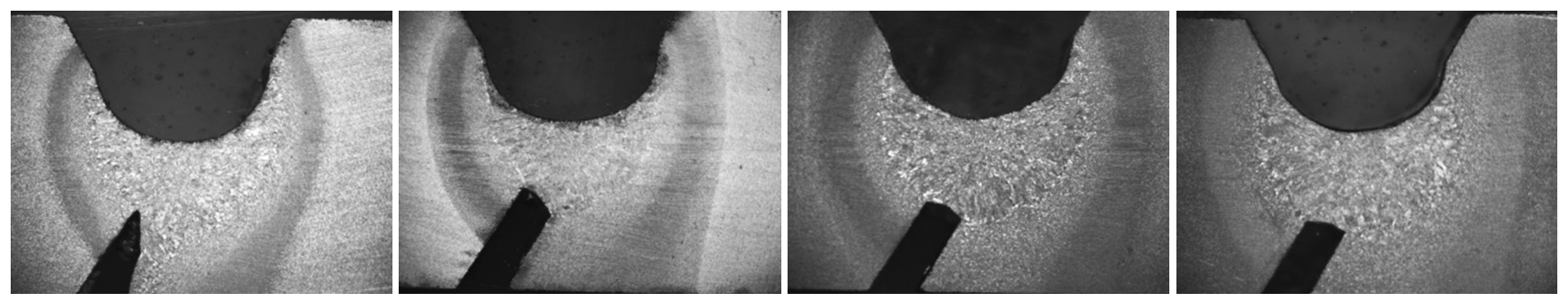

Rys. 5. Makrostruktura złącza spawanego S500ML, osłona $\mathrm{Ar}+5 \% \mathrm{H}_{2}$

Fig. 5. Macrostructure of S500ML welded joints, shielding gas $\mathrm{Ar}+5 \% \mathrm{H}_{2}$
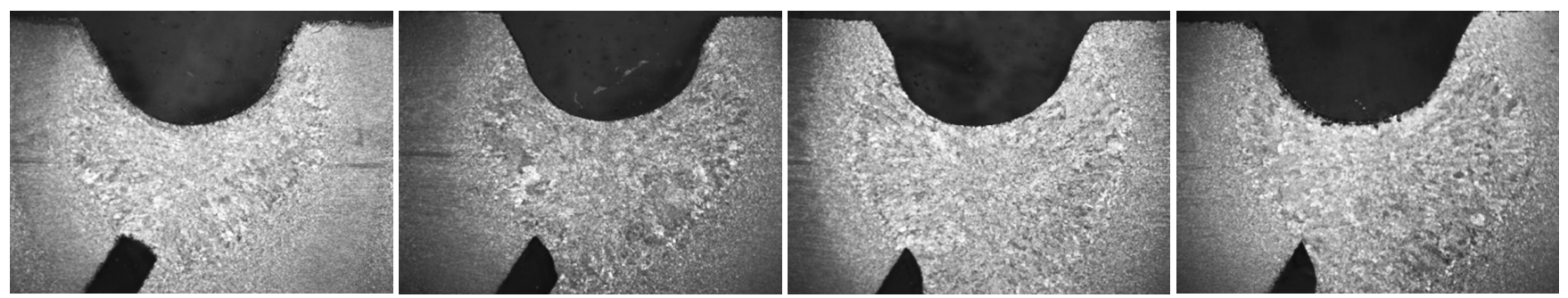

Rys. 6. Makrostruktura złącza spawanego S500ML, osłona $\mathrm{Ar}+10 \% \mathrm{H}_{2}$

Fig. 6. Macrostructure of S500ML welded joints, shielding gas $\mathrm{Ar}+10 \% \mathrm{H}_{2}$

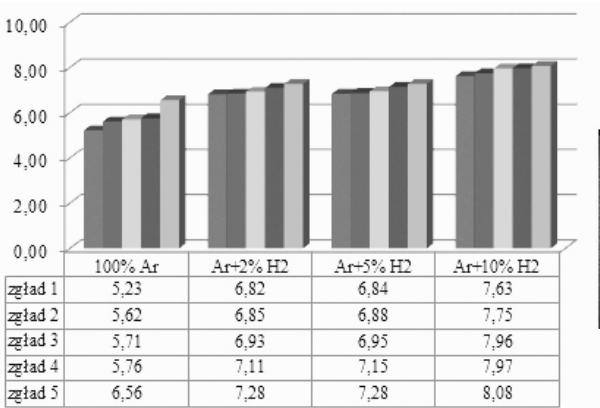

Rys. 7. Porównanie głębokości wtopienia - stal S500ML

Fig. 7. Comparison of the depth of penetration - S500ML steel

Na wykresach (rys. 7 i rys. 8) wyraźnie widać tendencję do równomiernego układania się spoiny niezależnie od ilości zastosowanego dodatku wodoru. Widać też, że czas niezbędny do termicznego ustabilizowania procesu spawania z zastosowaniem osłony $100 \%$ Ar jest dłuższy.

W próbkach z pozostałych dwóch gatunków stali, czyli S700MC i S700MC E nie stwierdzono tak dużych różnic

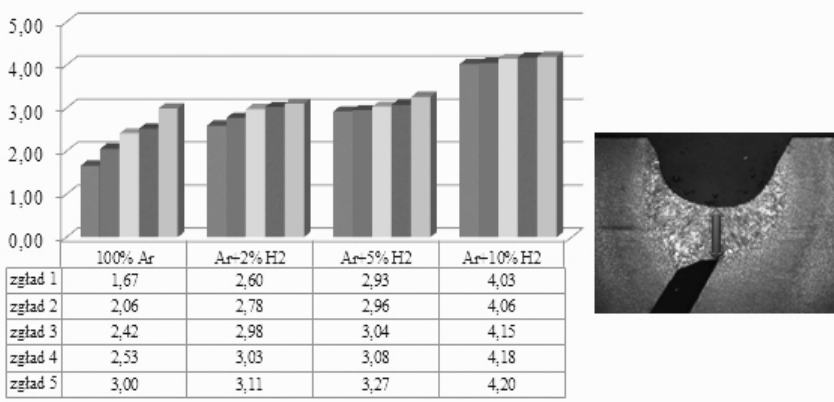

Rys. 8. Grubość spoiny - stal S500ML

Fig. 8. Thickness of joints - S500ML steel

i stanowiły one 3 do $4 \%$ wzrost głębokości w badaniu spoin wykonanych z $2 \%$ i $5 \%$ dodatkiem wodoru oraz o $11 \%$ głębsze wtopienie, gdy wodoru w mieszance było $10 \%$, przy pomiarze liczonym od powierzchni spawanego materiału. Wynik pomiaru grubości spoiny zwiększył się odpowiednio o 2\%, 3\% i 22\% dla poszczególnych mieszanek w porównaniu do złączy spawanych w czystym Ar. 


\section{Wnioski}

Mając na uwadze korzystne aspekty dodatku wodoru do mieszanki spawalniczej, ale i jego szkodliwy wpływ na metale i stopy można przyjąć, że niewielki, ściśle kontrolowany dodatek wodoru do osłony argonowej chroniącej jeziorko ciekłego metalu nie ma wpływu na występowanie pęknięć w złączach spawanych o charakterze pęknięć wodorowych.

Badania przeprowadzone w czasie spawania drobnoziarnistych stali ferrytycznych o minimalnej granicy plastyczności $500 \mathrm{MPa}$ i $700 \mathrm{MPa}$, w osłonie 2\%, 5\% i 10\% dodatku wodoru do argonu, wykazują brak wpływu na zwłoczne pęknięcia wodorowe i potwierdzają technologiczną możliwość stosowania tych mieszanek, pod warunkiem znormalizowanego kwalifikowania technologii spawania. Innymi słowy, spawanie elektrodą nietopliwą w atmosferze ww. mieszanek pozwala na wykonanie wysokiej jakości złączy, charakteryzujących się głębszym przetopem, większą gładkością lica oraz mniejszą skłonnością do podtopień krawędzi w porównaniu do złączy wykonanych w osłonie czystego argonu. Przeprowadzone doświadczenia wskazują, że przy spawaniu wyrobów ze stali konstrukcyjnych zwykłej jakości takie mieszanki mogą być nawet zalecane, szczególnie gdy konieczne jest uzyskanie dobrej jakości złącza o estetycznym wyglądzie. Dotyczy to większości wyrobów spawanych ze stali ferrytycznych i austenitycznych, takich jak np.: meble metalowe, obudowy maszyn czy AGD.

Należy przy tym pamiętać, że obecność wodoru w strukturze stali może być przyczyną awarii maszyn czy urządzeń, również tych niespawanych. Dlatego też jest niezmiernie ważne przestrzeganie wymagań technologicznych dotyczących odpowiedniego przygotowania złączy przed spawaniem w sposób gwarantujący brak dostępu wodoru innego niż ten zawarty w mieszance osłonowej na bazie argonu.

\section{Literatura}

[1] Sałaciński T.: Inżynieria jakości w technikach wytwarzania, Oficyna Wydawnicza Politechniki Warszawskiej, 2016.

[2] Sałaciński T.: SPC Statistical Process Control, Oficyna Wydawnicza Politechniki Warszawskiej, 2016.

[3] Sałaciński T., Sosnowski W.: System nadzorowania jakości procesów spawalniczych zgodny z wymaganiami ISO $3834 \mathrm{w}$ oparciu o standardy ISO 9001. Cz. 2, Przegląd Spawalnictwa, vol. 87, nr 4, 2015, s. 10-13.

[4] Krajewski A., Hudycz M.: Zapewnienie jakości i kontrola złączy spajanych, Oficyna Wydawnicza Politechniki Warszawskiej, 2015.

[5] Chmielewski T.: Projektowanie procesów technologicznych - Spawalnictwo, Oficyna Wydawnicza Politechniki Warszawskiej, 2013.

[6] Wojnarowski K., Skowrońska B., Chmielewski T., Golański D.: Porównanie warunków spawania różnych grubości złącza ø1016 stali L485ME metodą 135/136, Przegląd Spawalnictwa, vol. 90, nr 5, 2018, s. 155-159.

[7] Jaeschke B., Węglowski M., Chmielewski T.: Current State and Development Opportunities of Dynamic Power Source for GMA Welding Processes, Journal of Manufacturing Technologies 42 (1), 2017, pp. 23-30.

[8] Ferenc K., Cegielski P., Chmielewski T.: Technika spawalnicza w praktyce, Poradnik inżyniera, konstruktora i spawacza, Verlag Dashofer, 2009.

[9] Ferenc K., Ferenc J.: Spawalnicze gazy osłonowe i palne, WNT, Warszawa, 2013.

[10] Ferenc K.: Spawalnictwo, WNT, Warszawa, 2013.

[11] Skowrońska B., Szulc J., Chmielewski T., Golański D.: Wybrane właściwości złączy spawanych stali S700 MC wykonanych metodą hybrydową plazma+MAG, Przegląd Spawalnictwa vol. 89, nr 10, 2017, s. 104-111.

[12] Chmielewski T., Węglowski M.: Analiza rynku spawalniczego w Polsce pod względem sprzedaży urządzeń oraz materiałów spawalniczych, Przegląd Spawalnictwa, vol. 82, nr 6, 2010, s. 28-31.

[13] Szulc J., Chmielewski T., Pilat Z.: Zrobotyzowane spawanie hybrydowe Plazma+MAG stali S700 MC, Przegląd Spawalnictwa, vol. 88, nr 1, 2016, s. 41-45.

[14] Węglowski M., Chmielewski T., Kudła K.: Porównanie wybranych właściwości nowoczesnych spawalniczych inwertorowych źródeł energii przeznaczonych do spawania metodą MAG, Przegląd Spawalnictwa vol. 81, nr 10, 2009, s. 81-83.
[15] Węglowski M., Chmielewski T., Kudła K.: Ocena wydajności spawania w wysoko wydajnym procesie SpeedUp oraz MAG Standard w pozycji przymusowej, Biuletyn Instytutu Spawalnictwa w Gliwicach 54, 2010, s. $199-201$.

[16] Klimpel A.: Spawanie, zgrzewanie i cięcie metali, WNT, Warszawa, 1999.

[17] Tasak E.: Metalurgia spawania, Wydawnictwo JAK, Kraków, 2008.

[18] Fydrych D., Rogalski G., Świerczyńska A., Łabanowski J.: Możliwości sterowania ilością wodoru dyfundującego w złączach spawanych, Przegląd Spawalnictwa, vol. 89, nr 10, 2017, s. 21-26.

[19] Fydrych D.: Wpływ warunków spawania na skłonność do tworzenia pęknięć zimnych przy spawaniu pod wodą, PhD thesis, Gdańsk University of Technology, Gdańsk, 2005.

[20] Fydrych D., Łabanowski J.: An experimental study of high-hydrogen weIding processes, Revista de Metalurgia 51 (4), 10.3989/revmetalm.055, 2015.

[21] Fydrych D., Rogalski G.: Wpływ warunków spawania mokrego elektrodą otuloną na zawartość wodoru dyfundującego w stopiwie, Przegląd Spawalnictwa, vol. 80, nr 2, 2008, s. 3-8.

[22] Fydrych D., Świerczyńska A., Rogalski G.: Diffusible hydrogen content in the deposited metal of multilayer welded joints, Metallurgy and Foundry Engineering, vol. 40 (4), 2014, pp. 221-229.

[23] Górka J.: Właściwości i struktura złączy spawanych stali obrabianej termomechanicznie o wysokiej granicy plastyczności, Monografia, Wydawnictwo Politechniki Śląskiej, Gliwice 2013.

[24] Górka J.: Właściwości spoin stali obrabianych termomechanicznie o wysokiej granicy plastyczności, Przegląd Spawalnictwa vol. 83, nr 12, 2011, s. 31-35.

[25] Górka J.: Stal obrabiana termomechanicznie S700 MC i jej spawalność, Biuletyn Instytutu Spawalnictwa 6/2012. 